\title{
Multifaceted Asylum Triangle: Does Fragmentation of the Right to Asylum and the Non-Refoulement Rule Deters the Functioning of Equitable and Predictable Burden- and Responsibility-Sharing Mechanism on Refugees?
}

Tamta Zaalishvili*

DOI: 10.21827/GroJIL.9.1.174-194

Key words:

ASYLUM; NON-REFOULEMENT; FRAGMENTATION; BURDEN- AND RESPONSIBILITY-SHARING

\begin{abstract}
The global refugee protection system is founded on two core values, assuring a safe and dignified life away from violent regimes and conflicts: the right to asylum and the nonrefoulement rule. While there are no internationally agreed definitions for these concepts, their fragmentation affects the equitable and predictable burden- and responsibilitysharing, and subsequently, successful international cooperation in refugee matters.

By analysing the right to asylum in legal theory and examining its application in the jurisprudence of international human rights monitoring bodies, this article seeks to explore the complexity of heterogeneous approaches with regard to refugees. Furthermore, the impediments to the functioning of the current refugee protection regime is identified by analysing the complicated nature of its umbrella maxim - the nonrefoulement rule. The article examines how the lack of clarity on the contents of the right to asylum and the non-refoulement rule causes different, sometimes contradictory, approaches regarding the corresponding international obligations of states. It further explores how the diversified understanding of these foundational principles makes it difficult to identify common protection needs and the responsibilities of states with regard to international cooperation and burden- and responsibility-sharing on refugee matters.

Eventually, the fragmentation of these core values threatens their unequivocal application and results in failing refugee protection regimes. Consequently, this article argues that a common understanding on the right to asylum and non-refoulement rule represents a condicio sine qua non for securing equitable and predictable burden- and responsibility-sharing mechanism in refugee matters.
\end{abstract}

\section{Introduction}

Is there a universally recognised understanding of the right to asylum or is it fragmented between the rights to seek, be granted and enjoy asylum? What is the normative composition of its protective shield - the non-refoulement rule? How does the nature of their application underpin the efficiency of international cooperation in refugee matters?

At the dawn of honouring human rights, humankind has witnessed untold cruelty resulting in mass human displacement in every corner of the world, some headed towards more unfortunate places. In the fullness of time, the problems faced by asylum seekers and their right to asylum have received considerable attention. Eventually, the

\footnotetext{
* Ms. Tamta Zaalishvili is Lecturer at Ivane Javakhishvili Tbilisi State University, e-mail: tamta.zaalishvili@tsu.ge.
} 
scope of protection for those forcibly displaced internationally from their homeland has gradually extended alongside the increase in humanitarian sentiments among people. This was especially felt upon the creation of regional, international and supranational organisations, with the purpose of peacefully resolving existing challenges among states regarding the protection of human rights, including those of forcibly displaced people. By establishing the legal framework of protection and providing the solutions for refugees, states and international community assumed their responsibility for those persons who are forced to flee their countries. The current international refugee protection regime has attributed firm a bond between refugees and their receiving states. ${ }^{1}$ Still, in the face of today's challenges, the current refugee protection regime has retained its 'enduring value and relevance in the twenty-first century'.

Notwithstanding massive legal developments on the forced displacement throughout the 20th century, the fragmentation and vagueness of the right to asylum the core principle of the refugee protection system remains an issue and a matter of scholarly inquiry. ${ }^{3}$ Until recently, this concern has remained high on the global refugee agenda. Currently, of the total 79.5 million forcibly displaced persons in the world, 33.8 million are refugees or asylum seekers; $77 \%$ of them still remain in protracted situations. ${ }^{4}$ While the international community has affirmed its willingness to equitable and predictable burden- and responsibility-sharing ${ }^{5}$ on refugee matters by adopting the Global Compact on Refugees, states have varying, sometimes even contrasting, approaches to addressing protection needs.

The ambiguous understanding of the foundational principles of refugee protection regime, the right to asylum and the non-refoulement rule, makes it a challenge to identify common protection needs and therefore, the respective responsibilities of states regarding international cooperation and burden- and responsibility-sharing on refugee matters. The global refugee regime suffers from an apparent lack of identification of the relevant responsibilities of states towards asylum seekers and refugees within the scope of the right to asylum and non-refoulement rule. Consequently, the lack of common understanding of the right to asylum and the non-refoulement rule threatens their unequivocal application and can jeopardise the functioning of the global refugee protection regime.

While seeking to examine major safeguards of the global refugee regime, Part one of this article introduces the analysis on the controversial nature of the right to asylum from the lenses of legal theory and treaty law by exploring the non-refoulement rule under international refugee law, customary law and human rights protection regime. Part two analyses its protecting, supporting and endorsing role towards the enforceability of the right to asylum. Finally, Part three lays out the indispensability of a common

James C Hathaway, The Rights of Refugees under International Law (CUP 2005) 154.

UN High Commissioner for Refugees (UNHCR), Ministerial Communiqué, HCR/MINCOMMS/2011/6 (8 December 2011); Guy S Goodwin-Gill and Jane McAdam, The Refugee in International Law (3rd edn, OUP 2007) 47.

3 María-Teresa Gil-Bazo, 'Asylum as a General Principle of International Law'(2015) 27(1) IJRL 4, 6, 9; Atle Grahl-Madsen, The Status of Refugees in International Law (vol I Sijthoff 1966) and (vol II Sijthoff 1972); Chama LC Mubanga-Chipoya, 'The Right of Everyone to Leave any Country, Including His Own, and to Return to His Country’, Doc.E/C.4/Sub.2/1988/35, 103-106.

4 UNHCR, 'Global trends: Forced Displacement in 2019' (2020) 2 <https://www.unhcr.org/statistics/unhcrstats/5ee200e37/unhcr-global-trends-2019.html> accessed 16 January 2021.

5 UNGA Res 73/151 (17 December 2018) UN Doc A/73/12 (Part II) (Global Compact on Refugees) Part III (A). 
understanding of the right to asylum and the non-refoulement rule for the functioning of equitable and predictable burden- and responsibility-sharing mechanism.

\section{A. The Diversified Right to Asylum}

International jurisprudence, treaty law and international practice regarding the right to asylum is fairly extensive; however, there is no internationally agreed definition of this right in the legal world, ${ }^{6}$ and the vagueness of this institution ${ }^{7}$ remains a concern even in recent times. ${ }^{8}$ What is the scope and extent of the right to asylum? Does it solely enshrine the right to seek and enjoy asylum or does it refer to the right to be granted asylum as well? Correspondingly, what is the legal nature of the right of a receiving state to grant asylum? Overall, how enforceable is the right to asylum and does it impose any kind of obligation(s) towards states, and importantly, how do these rights correlate with each other?

\section{i. The Asylum Dilemma: 'right of everyone' or 'sovereign prerogative'?}

Although one can trace the origins of the right to asylum back to ancient times, the concept has evolved over the centuries. ${ }^{9}$ As Grotius put down in the 17th century: "a permanent residence [ought not] to be refused to foreigners, who, driven from their own country, seek a place of refuge." ${ }^{10}$ However, it was in 1948, when 48 member states of the United Nations adopted the Universal Declaration of Human Rights (UDHR), ${ }^{11}$ a milestone document in the history of human rights protection, stating in its Article 14(1) that "everyone has the right to seek and to enjoy in other countries asylum from persecution". While the language of the article referred to the right of a person to seek and enjoy asylum, the Declaration stayed silent regarding the counter obligation(s) of states and such reticence was not unintentional.

Before the adoption of the Declaration, it was discussed during the preparatory works that "it had been a mistake [...] to recognise the individual right to seek asylum while neither imposing upon states the obligation to grant it nor invoking the support of the United Nations". ${ }^{2}$ Indeed, the original text of article 14(1) provided that "everyone has the right to seek and be granted, in other countries, asylum from persecution". ${ }^{13}$ However, the term "and be granted" was altered with much acknowledged and endorsed provision by the majority of states: ${ }^{14}$ "and to enjoy" ${ }^{15}$ excluding the obligation of states to grant asylum to those who seek it. ${ }^{16}$ "The right to be granted asylum" was left

\footnotetext{
6 Elena Fiddian-Qasmiyeh, Gil Loescher, Katy Long, and Nando Sigona (eds), The Oxford Handbook of Refugee and Forced Migration Studies (OUP 2014) 42.

7 Goodwin-Gill and McAdam (n 2) 358.

8 Gil-Bazo (n 3) 10 .

9 The right of sanctuary was enshrined in the Code of Theodosius, the Justinian Code, the Papal sanction; see also, A Grahl-Madsen, Territorial Asylum (Almqvist \& Wiksell International 1980); E Reale, 'Le droit d'asile' (1938) Recueil des Cours de l'Académie de Droit International de La Haye 63(1), 473.

10 Hugo Grotius, De iure belli ac pacis, libri duo (AC Campbell tr, Batoche Books 2001) 84.

11 Universal Declaration of Human Rights (adopted 10 December 1948) UNGA Res 217 A(III).

12 UNGA, Summary Records of Meetings, Part 1: 3rd Session, 122nd Meeting (4 November 1948) UN Doc A/C.2/SR.56-85, 347 (Mr Cassin, France).

13 UNGA, Summary Records of Meetings, Part 1: 3rd Session, 119th Meeting (30 October 1948) UN Doc A/C.3/285/Rev.1.

14 UNGA, Summary Records of Meetings, Part 1: 3rd Session, 122nd Meeting (4 November 1948) UN Doc A/C.2/SR.56-85, 345 (Mr Saint-Lot, Haiti), 345 (Miss Zuloaga, Venezuela), 346 (Mr Contoumas, Greece).

15 ibid.

16 Goodwin-Gill and McAdam (n 2) 358-359.
} 
unaddressed by the Drafting Committee of the 1951 Refugee Convention as well, ${ }^{17}$ with only a mention of it in Recital 4 of its Preamble. ${ }^{18}$

Therefore, states objected to "formulas implying obligation"19 and the right to grant asylum was perceived as a "sovereign prerogative", ${ }^{20}$ and "a discretionary act of the state". ${ }^{21}$

\section{ii. In attempting to fill in remaining gaps}

The concerns surrounding the content of the right to asylum remained after the adoption of the 1951 Refugee Convention. The International Law Commission and the UN Commission on Human Rights further conducted substantial work to address the remaining gaps which was concluded with the adoption of the 1967 UN Declaration on Territorial Asylum. ${ }^{22}$ Yet, "the right to be granted asylum" was left unaddressed under international treaty law, and its regulation remained under the discretion of domestic legal systems. ${ }^{23}$

In the years to come, the right to seek and enjoy asylum attained widespread recognition $^{24}$ in regional conventions, such as the Caracas Convention, ${ }^{25}$ the Organisation of African Unity (OAU) Convention, ${ }^{26}$ and Council of Europe Resolution (67)14. ${ }^{27}$ The concepts of the right to seek and enjoy asylum were also applied in regional arrangements, such as the comprehensive programmes for Central America (CIREFCA), Indo-China (CPA), Central European Asylum System (CEAS), etc. ${ }^{28}$ The everincreasing pattern of forced displacement further placed the concept of asylum at the centre of global legal discourse. The 2016 New York Declaration for Refugees and Migrants reaffirmed "respect for the institution of asylum and the right to seek asylum", ${ }^{29}$ however, explicitly recognised "that the ability of refugees to lodge asylum claims in the country of their choice may be regulated, subject to the safeguard that they will have access to, and enjoyment of, protection elsewhere". ${ }^{30}$ Similarly, the 2018 Global

17 ibid 362; R Alleweldt, 'Preamble to the 1951 Convention' in Andreas Zimmermann, Felix Machts, Jonas Dörschner (eds), The 1951 Convention Relating to the Status of Refugees and its 1967 Protocol: A Commentary (OUP 2011) 236-238.

18 Convention Relating to the Status of Refugees (adopted 28 July 1951, entered into force 22 April 1954) 189 UNTS 137 (Refugee Convention), Preamble, recital 4.

19 Goodwin-Gill and McAdam (n 2) 359.

20 ibid 358-359.

21 Agnès Hurwitz, The Collective Responsibility of States to Protect Refugees (OUP 2009) 16; Declaration on Territorial Asylum (adopted 14 December 1967) UNGA Res 2312(XXII) (Declaration on Territorial Asylum) article 3; Paul Weis, 'The United Nations Declaration on Territorial Asylum' (1969) 7(92) CYBIL 92, 137-9.

22 Declaration on Territorial Asylum; Goodwin-Gill and McAdam (n 2) 363; Weis, 'The United Nations Declaration on Territorial Asylum' (n 21) 97-99.

23 Hurwitz, The Collective Responsibility of States to Protect Refugees (n 21) 16.

24 ibid; see also Paul Weis, 'Territorial Asylum' (1966) 6(2) Indian Journal of International Law 173, 194.

25 Convention on Territorial Asylum (adopted 28 March 1954, entered into force 29 December 1954) 1438 UNTS 127 (Caracas Convention) arts 1-4.

26 Convention Governing the Specific Aspects of Refugee Problems in Africa (adopted 10 September 1969, entered into force 20 June 1974) 1001 UNTS 45 (OAU Convention) art II.

27 CoE Committee of Ministers Resolution (67) 14 (29 June 1967).

28 See further, Goodwin-Gill and McAdam (n 2) 365.

29 'New York Declaration for Refugees and Migrants', UNGA Res 71/1 (3 October 2016) (New York Declaration) 67, 3, 24, 27.

30 ibid 70. 
Compact on Refugees recognised the right to asylum as the grounding element of the international refugee protection regime ${ }^{31}$ and further reaffirmed the importance of fair and efficient status determination to all those who are in need to find and enjoy international protection. ${ }^{32}$

Therefore, the subsequent legislative developments after the UDHR reaffirmed its initial approach, yet leaving ${ }^{33}$ core questions unaddressed; namely, what is the composition of the right to asylum, and how do its constituent elements correlate with each other?

\section{iii. Conflicting or compossible ${ }^{34}$ rights?!}

The concept of asylum has retained its role as 'central to the refugee protection paradigm' 35 and undoubtedly, has its special normative force. ${ }^{36}$ Nevertheless, how did the right to asylum become imbued with this prescriptive proposition? Alternatively, to frame this dilemma under Kant's deductive quaestio iuris ${ }^{37}$ - by what right do we think ourselves as holders of the right to asylum?

If we consult the widely acknowledged Hohfeldian Analytical System, ${ }^{38}$ the right to seek, the right to grant, the rights to be granted and enjoy asylum can be described as independent, "atomic" rights with diverse characteristics and subjects; however, when they band together, they form a complex, "molecular" right to asylum.

The right to seek asylum, owned by non-citizens who are outside of their country of origin, represents a privilege and a claim of the right holder. It obliges the receiving state to allow asylum seekers onto its territory and provide a fair and efficient asylum procedure. On the other hand, the state's discretionary right to grant asylum signifies that the state is the sole sovereign on its territory, acting under its legislation and sovereign interests. It gives complete discretion to the receiving state to grant or keep providing international protection, equipping the state with the power to alter the normative situation of asylum seeker and international protection holder, when required. Meanwhile, asylum seekers can make a claim towards the receiving state to be granted asylum - and similarly, the international protection holders can claim the right to enjoy asylum. However, the rights to be granted and to enjoy asylum are not limitless and can be restricted by the superior right of a state to grant or withdraw asylum.

Overall, the right to asylum is a complex, "molecular" right, characterised by multiple subjective parts, implying exclusive prerogatives on both sides - those who seek or grant it. Revealing the interdependence between "atomic" rights within the right to asylum does not exhaustively uncover its character and the asylum dilemma remains unresolved. As the accelerated transformation of the institution of asylum was profoundly caused by the growth in the global forced displacement crisis, the legal history and practice have revealed the direct linkage between the right to asylum and the prohibition of refoulement, the founding principle of the refugee protection system.

\footnotetext{
31 Global Compact on Refugees (n 5).

32 ibid 5, 61; UNHCR Executive Committee (ExCom) Conclusions Nos 103 (2005) and 96 (2003).

33 Gil-Bazo (n 3) 8.

34 Hillel Steiner, An Essay on Rights (Blackwell 1994); see also Edward N Zalta (ed), 'Rights' (2015) The Stanford Encyclopedia of Philosophy <https://plato.stanford.edu/entries/rights/> accessed 22 October 2020.

35 Hurwitz, The Collective Responsibility of States to Protect Refugees (n 21) 17.

36 Zalta, 'Rights' (n 34).

37 Immanuel Kant, Kant's Critiques: The Critique of Pure Reason, the Critique of Practical Reason, the Critique of Judgement (A \& D Publishing 2008).

38 Zalta, 'Rights' (n 34).
} 


\section{The Non-Refoulement Rule as a Supporting Shield to the Well-Functioning Refugee Protection Regime - Misconceptions and Reality}

Legal theorists argue that if the realisation of a right is an important precondition for the enjoyment of another right, the former has a strong supporting role for the latter. ${ }^{39}$ Likewise, as Shue assumes, rights that are indispensable for the full enjoyment of all other rights are "basic rights". ${ }^{40}$ Such a "linkage argument" ${ }^{41}$ can be used to defend the non-refoulement rule as a basic, supportive right for the implementation of the refugee protection regime and ultimately, the right to asylum. The non-refoulement rule prohibits transfer or removal of a person given the substantial grounds for believing of risk of irreparable harm upon return. ${ }^{42}$ By doing so, if we borrow Nickel's ${ }^{43}$ typology of supporting relations between rights, ${ }^{44}$ the right to be protected under the non-refoulement rule strongly supports the right to asylum.

Furthermore, by applying Dworkin's and Mill's metaphors, the non-refoulement rule can be considered as a "trumping power", ${ }^{45}$ which represents an umbrella maxim for guaranteeing the successful implementation of the right to seek, be granted and enjoy asylum as it obliges the receiving state not to return asylum seekers and international protection holders in the place where their life or freedom might be in danger.

By analysing the non-refoulement rule through the lenses of international human rights law, international refugee law and customary international law, this Section attempts to identify the nature of the "support" provided by the non-refoulement rule to the right to asylum. ${ }^{46}$

\section{A. The indispensability of the non-refoulement rule for the enforcement of refugee protection regime: refugee law perspective}

States did 'exchange' their nationals in the spirit of reciprocity since the ancient times. ${ }^{47}$ The objection of refouler of those who were in need of asylum emerged since the 19th century $^{48}$ alongside the development of the idea that non-citizens fleeing their tyrannical governments might be in need of protection from the host state, in certain circumstances, where their return would cause their persecution or punishment based on political or

39 See generally Henry Shue, Basic Rights: Subsistence, Affluence, and US Foreign Policy (PUP 1996); Amartya Sen, Development as Freedom (OUP 1999).

40 Shue (n 39).

41 ibid.

42 See UNHCR, 'Advisory Opinion on the Extraterritorial Application of Non-Refoulement Obligations under the 1951 Convention Relating to the Status of Refugees and its 1967 Protocol' (26 January 2007) available at <https://www.refworld.org/docid/45f17a1a4.html> accessed: 09 September 2021.

43 James Nickel, 'Rethinking Indivisibility: Towards a Theory of Supporting Relations between Human Rights' (2008) 30(4) HRQ 984; James Nickel, 'Indivisibility and Linkage Arguments: A Reply to Gilabert' (2010) 32 HRQ 439.

44 See also, Pablo Gilabert, 'The Importance of Linkage Arguments for the Theory and Practice of Human Rights: A Response to James Nickel' (2010) 32 HRQ 425.

45 Ronald Dworkin, 'Rights as Trumps', in Jeremy Waldron (ed), Theories of Rights (OUP 1984) 153-67; John S Mill, On Liberty and Other Essays (Stefan Collini ed, CUP 1989) 20.

46 See, Gil-Bazo (n 3) 8-9; Paul Weis, 'The Development of Refugee Law' Transnational Legal Problems of Refugees (1982) 3 Michigan Yearbook of International Legal Studies 27, 38.

47 Goodwin-Gill and McAdam (n 2).

48 ibid 201. 
religious grounds. ${ }^{49}$ Alongside the global displacement caused by major conflicts, the legal scope and application of the non-refoulement rule relatively extended throughout the legal instruments of international refugee law. The conventional declaration of the principle of non-refoulement occurred in 1933 with the adoption of the Convention relating to the International Status of Refugees, ${ }^{50}$ which was the ever first attempt of creating a comprehensive legal framework for the refugee protection. ${ }^{51}$ As Goodwin-Gill and McAdam note, "the need for protective principles for refugees began to emerge, but limited ratifications of instruments containing equivocal and much qualified provisions effectively prevented the consolidation of a formal principle of non-refoulement". ${ }^{52}$

Large-scale displacement ${ }^{53}$ caused by war and human rights abuses during and after the Second World War should have given an impulse to furthering the scope of the principle of non-refoulement for ensuring the realisation of the right to asylum. Shortly after the establishment of the United Nations, the General Assembly adopted Resolution $8(1)$ allowing refugees to stay in their host states if having 'valid objections' for returning to their countries of origin. ${ }^{54}$ This was followed by the introduction of the provision of non-refoulement in 1950 in the draft Convention on the International Status of Refugees. ${ }^{55}$ The draft provision was absolute, not including any exceptions from the rule ${ }^{56}$ but as consequent events illustrated, "the change in the international situation" 57 led the 1951 Conference of Plenipotentiaries to fade the absoluteness of the principle of nonrefoulement by adding exceptions to the application of the rule, such as public order and national security. ${ }^{58}$ Nonetheless, as Lauterpacht and Bethlehem observed, consideration of the special circumstances in article 33(2) did not give states unlimited margin of appreciation for restricting the applicability of non-refoulement rule, as the probable individual consequences of refoulement should be assessed. ${ }^{59}$ Accordingly, it was assumed that the derogation from the non-refoulement rule was allowed solely while having "reasonable grounds" for believing that there existed a very precise threshold of perspective danger for national security or public order. ${ }^{60}$ Eventually, Article 33 of the Refugee Convention was adopted with enshrined limitations, alongside Article 42(1), which prohibited any reservation to the rule. ${ }^{61}$

The debate regarding the scope of the states' obligations of non-refoulement continued early after the adoption of the 1951 Refugee Convention. The discourse mostly referred to whether the principle exclusively protected refugees already present on the

49 See for example Clive Parry and Sir Gerald Fitzmaurice (eds), British Digest of International Law (vol 6, Stevens 1965) 53-4, 64-5.

50 Goodwin-Gill and McAdam (n 2) 202; Zimmermann, Machts, Dörschner (n 17) 1399-1401.

51 Peter Fitzmaurice, 'Anniversary of the forgotten Convention: 1933 Refugee Convention and the Search for Protection between the World Wars' (2013) 8(1) RDC 1, 2.

52 Goodwin-Gill and McAdam (n 2) 203.

53 John A S Grenville, A History of the World From the 20th to the 21st Century (Routledge 2005) 310.

54 UNGA Res 8(I) (12 February 1946) A/RES/8(I) [c(ii)].

55 UNESC Res 248 (IX)B (8 August 1949) UN Doc E/OR(IX)/Suppl. No. 1; UNGA Res 429(V) (14 December 1950) A/RES/429.

56 UN Ad Hoc Committee on Refugees and Stateless Persons, Report of the Ad Hoc Committee of 14 August to 25 August 1950, Second Session, Geneva, 14 August to 25 August 1950 (25 August 1950) UN Doc E/AC.32/8;E/1850 [30].

57 Goodwin-Gill and McAdam (n 2) 204.

58 Refugee Convention art 33(2).

59 Elihu Lauterpacht and Daniel Bethlehem, 'The Scope and Content of the Principle of Non-Refoulement: Opinion' in Erika Feller, Volker Türk and Frances Nicholson (eds), Refugee Protection in International Law: UNHCR's Global Consultations on International Protection (CUP 2003) 168, 169.

60 ibid 168-169.

61 Refugee Convention art 42(1). 
territory of the receiving state or those at the frontiers as well. It was questionable whether it guaranteed "no duty to admit" policy for states, or, on the contrary, indirectly referred to the duty to grant asylum - interpretation highly unwelcomed by a majority of states. ${ }^{62}$ UNHCR in its Advisory Opinion of 2007 explicitly affirmed the applicability of the principle of non-refoulement to "any form of forcible removal, including deportation, expulsion, extradition, informal transfer or "renditions", and non-admission at the border". ${ }^{63}$ The UNHCR Executive Committee has consistently reaffirmed the "fundamental importance" of the principle of non-refoulement. ${ }^{64} \mathrm{With}$ the unparalleled increase of the forced displacement, the international instruments ${ }^{65} \mathrm{UNHCR}$ Executive Committee conclusions, ${ }^{66}$ state practice ${ }^{67}$ and scholarly opinion ${ }^{68}$ through time, has affixed clarity ${ }^{69}$ to the Article 33 of the Refugee Convention, now encompassing both, non-return and non-rejection, ${ }^{70}$ irrespective of where does asylum-seeker present himself for entry, within a state or at its border. ${ }^{71}$

Any individual who has a well-founded fear of being persecuted on grounds of race, religion, nationality, membership of a particular social group, or political opinion, is protected under non-refoulement rule in the light of Article 1(A) of the 1951 Refugee Convention. The UN General Assembly and UNHCR Executive Committee have

62 United Nations, Conference of Plenipotentiaries on the Status of Refugees and Stateless Persons: Summary Record of the Sixteenth Meeting (23 November 1951) UN Doc A/CONF.2/SR.16 regarding art 6 and art 11, Summary Record of the Thirty-fifth Meeting (3 December 1951) UN Doc A/CONF.2/SR.35 regarding art 21; Paul Weis, 'Legal Aspects of the Convention of 28 July 1951 relating to the Status of Refugees', (1953) 30 BYBIL 478, 482, 487.

63 UNHCR Advisory Opinion (n 42) 7.

64 UNHCR ExCom Conclusion 68 (1992) [f]; UNHCR ExCom Conclusion 71 (1993) [g]; UNHCR ExCom Conclusion 74 (1994) [g]; UNHCR ExCom Conclusion 79 (1996) [j]; UNHCR ExCom Conclusion 81 (1997) [i]; UNHCR ExCom Conclusion 82 (1997) [i].

65 OAU Convention art II(3); CoE Committee of Ministers Resolution (67) 14 (n 27); Declaration on Territorial Asylum art 3(1); AALCO, '1966 Bangkok Principles on the Status and Treatment of Refugees' (final text as adopted on 24 June 2001) art III; Council Directive 2004/83/EC of 29 April 2004 on Minimum Standards for the Qualification and Status of Third Country Nationals or Stateless Persons as Refugees or as Persons Who Otherwise Need International Protection and the Content of the Protection Granted [2004] OJ L 304/12304/23, art 21; Council Directive 2005/85/EC of 1 December 2005 on Minimum Standards on Procedures in Member States for Granting and Withdrawing Refugee Status [2006] OJ L 326, art 3(1); Council Directive 2011/95/EU of the European Parliament and of the Council of 13 December 2011 on standards for the qualification of third-country nationals or stateless persons as beneficiaries of international protection, for a uniform status for refugees or for persons eligible for subsidiary protection, and for the content of the protection granted (recast) [2011] OJ L 337/9-337/26 (Council Directive 2011/95/EU) Preamble (3, 48), art 21.

66 UNHCR ExCom Conclusion 6 (1977) [c]; UNHCR ExCom Conclusion 22 (1981) [II(A)(2)]; UNHCR ExCom Conclusion 81 (1997) [h]; UNHCR ExCom Conclusion 82 (1997) [d(iii)].

67 Peter Collins, A Mandate to Protect and Assist Refugees: 20 years of Service in the Cause of Refugees, 1951 1971 (Office of the United Nations High Commissioner for Refugees 1971) 67-77.

68 Hurwitz, The Collective Responsibility of States to Protect Refugees (n 21) 176; Goodwin-Gill and McAdam (n 2) 207; Kay Hailbronner, 'Non-Refoulement and "Humanitarian" Refugees: Customary International Law or Wishful Legal Thinking?' in David Martin (ed), The New Asylum Seekers: Refugee Law in the 1980s (Nijhoff 1988) 123, 128; Atle Grahl-Madsen, The Status of Refugees in International Law vol 2 (Sijthoff 1972) 94.

69 cf Vienna Convention on the Law of Treaties (adopted 23 May 1969, entered into force 27 January 1980) 1155 UNTS 331 (VCLT) arts 31(1)(2).

70 Goodwin-Gill and McAdam (n 2) 208.

$71 \quad R$ (European Roma Rights Centre and others) v Immigration Office at Prague Airport (UNHCR Intervening) [2005] UKHL 55 [26] (Lord Bingham). 
reaffirmed multiple times that the principle of non-refoulement applies to asylum seekers as well, and therefore, the formal recognition of a person as a refugee is by no means a precondition for applying the non-refoulement rule upon him or her ${ }^{72}$ nor is it relevant how an asylum seeker reaches the territory of the state. ${ }^{73}$

The application of the principle of non-refoulement, alike numerous obligations in human rights protection regime, is linked to the exercise of state jurisdiction within its borders or extraterritorially. ${ }^{74}$ The prohibition of return applies to any territory where risk exists, irrespective of being a country of origin or not. ${ }^{75}$ The non-refoulement rule under the 1951 Refugee Convention does not enshrine any territorial limitations and prohibits return "in any manner whatsoever", ${ }^{76}$ irrespective if it occurs "beyond the national territory of the state in question, at border posts or other points of entry, in international zones, at transit points, etc." 77 Conversely, by imposing restrictive measures towards asylum seekers, including implementing containment policies and safe third country practices, states may conceivably breach their good faith obligations ${ }^{78}$ of availing protection under non-refoulement rule at the frontiers or in the territory of the state of destination. ${ }^{79}$ As Cantor assumes, "the human rights non-refoulement principle has a strong speculative aspect, i.e. it is engaged by the envisaged risk extraterritorially". ${ }^{80}$ Thus, the extraterritorial application of the principle of non-refoulement is effected, under Wilde's classification, with the "personal basis" rather than "spatial basis" for jurisdiction, ${ }^{81}$ since the state conduct is linked to an individual rather than some specific territory. ${ }^{82}$

Apart from that, the existence and scope of non-refoulement obligation in mass influx situations has also been highly debated as the concept of mass influx is not explicitly enshrined in the 1951 Refugee Convention and the 1967 Protocol, or in international refugee law jurisprudence. ${ }^{83}$ Lauterpacht and Bethlehem conclude that the principle of non-refoulement applies irrespective of the size and suddenness of the flow of asylum-seekers, as long as "the words of Article 33(1) give no reason to exclude the application of the principle to situations of mass influx". ${ }^{84}$ This approach is well

72 See, UNHCR ExCom Conclusion 6 (1977) [c]; UNHCR ExCom Conclusion 79 (1996) [j]; UNHCR ExCom Conclusion 81 (1997) [i]; UNHCR ExCom Conclusion 82 (1997) [d], [i]; UNGA res 52/103 (9 February 1998) [5]

73 Goodwin-Gill and McAdam (n 2) 233.

74 David J Cantor, 'Extraterritorial Non-refoulement: Intersections between Human Rights and Refugee Law' in Corinne Lennox (ed), Contemporary Challenges for Understanding and Securing Human Rights in Practice (School of Advanced Study 2015) 114; Hurwitz, The Collective Responsibility of States to Protect Refugees (n 21) 177.

75 Goodwin-Gill and McAdam (n 2) 250; Cantor, 'Extraterritorial Non-refoulement: Intersections between Human Rights and Refugee Law' (n 74) 114.

76 Goodwin-Gill and McAdam (n 2) 246.

77 Lauterpacht and Bethlehem (n 59) 67.

78 Hurwitz, The Collective Responsibility of States to Protect Refugees (n 21) 179; Joan Fitzpatrick, 'Revitalizing the 1951 Refugee Convention' (1996) 9 HHRJL 229, 237; Goodwin-Gill and McAdam (n 2) 221-3.

79 Hurwitz, The Collective Responsibility of States to Protect Refugees (n 21) 179; James C Hathaway and John A Dent, Refugee rights: Reports on a Comparative Survey (York Lane Press 1995) 14-15.

80 Cantor, 'Extraterritorial Non-refoulement: Intersections between Human Rights and Refugee Law' (n 74) 115.

81 Ralph Wilde, 'The "Legal Space” or "Espace Juridique” of the European Convention on Human Rights: Is It Relevant to Extraterritorial State Action?' (2005) 2 EHRLR 115, 116.

82 See UNHRC, 'Lopez Burgos v Uruguay, Saldias de Lopez (on behalf of Lopez Burgos) v Uruguay' (29 July 1981) CCPR/C/13/D/52/1979 [12.3]; UNHRC, 'Lilian Celiberti de Casariego v Uruguay' (29 July 1981) CCPR/C/13/D/56/1979 [10.3].

83 A Hurwitz, Mass Influx, in Immigration and Asylum from 1900 to the Present (Matthew J Gibney and Randall Hansen eds, ABC-CLIO 2005) 393, 394.

84 Lauterpacht and Bethlehem (n 59) 104. 
supported by numerous international instruments, including the OAU Convention, Cartagena Declaration, EU Temporary Protection Directive, and UNHCR conclusions. ${ }^{85}$ On the other hand, there is well-established assumption that "the prospect of a massive influx of refugees and asylum seekers exposes the limits of the state's obligation otherwise not to return or refuse admission to refugees". ${ }^{86}$ As Durieux and McAdam conclude, the mass influx situation might cause "a de facto suspension of all but the most immediate and compelling protections provided by the Convention" 87 considering the resources of the receiving states.

Consequently, the ever-increasing displacement challenges eventually troubled the scope of refugee protection and modified the content and scope of the non-refoulement rule, while doubling concerns regarding the efficiency and enforceability of refugee protection regime. ${ }^{88}$ And, as Edwards precisely assumed in $2005,{ }^{89}$ "it is at this juncture that human rights law has stepped in to fill in the "grey areas". ${ }^{90}$

\section{B. De facto right to asylum and prohibition of refoulement under human rights protection regime}

The adoption of treaties outside international refugee law and the development of international jurisprudence on international protection has evidenced the wider scope of the principle of non-refoulement beyond Article 33 of the 1951 Refugee Convention. ${ }^{91}$ The obligation not to return an individual to serious harm has been implicitly or explicitly stipulated ${ }^{92}$ in the jurisprudence of international human rights law, serving as de facto right to asylum. ${ }^{93}$

The practice of judicial (in case of the 1950 European Convention for the Protection of Human Rights and Fundamental Freedoms ${ }^{94}$ ) and quasi-judicial bodies (in case of the 1966 International Covenant on Civil and Political Rights and the 1984

85 OAU Convention art II(5); AALCO, Bangkok Principles (n 65) art 3.4; Cartagena Declaration on Refugees, adopted by the Colloquium on the International Protection of Refugees in Central America, Mexico and Panama (22 November 1984), annual Report of the Inter-American Commission on Human Rights, OAS soc OEA/Ser L/V/II 66/doc 10, rev 1, 190-93 (1984-85) (Cartagena Declaration on Refugees) art III(8); Council Directive 2001/55/EC of 20 July 2001 on Minimum Standards for Giving Temporary Protection in the Event of a Mass Influx of Displaced Persons and on Measures Promoting a Balance of Efforts Between Member States in Receiving such Persons and Bearing the Consequences Thereof [2001] OJ L212/12-212/23; UNHCR ExCom Conclusion 15 (1979) [f]; UNHCR ExCom Conclusion 19 (1980) [a], [b], [i]; UNHCR ExCom Conclusion 22 (1981) [II(A)(1)], [II(A)(2)]; UNHCR ExCom Conclusion 4 (1994) [r]; UNHCR, Protection of Refugees in Mass influx Situations: Overall Protection Framework, UN doc EC/GC/01/4 (19 February 2001) [6], [13].

86 Goodwin-Gill and McAdam (n 2) 243, 229-31.

87 Jean-Francois Durieux and Jane McAdam, 'Non-Refoulement through Time: The Case for a Derogation Clause to the Refugee Convention in Mass influx Emergencies' (2004) 16 IJRL 4, 9, 13.

88 Guy S Goodwin-Gill, 'Asylum 2001-A Convention and a Purpose' (2001) 13 IJRL 1, 1-2.

89 Alice Edwards, 'Human Security and the Rights of Refugees: Transcending Territorial and Disciplinary Borders' (2009) 30 MJIL 763, 792.

90 See Alice Edwards, 'Human Rights, Refugees and the Right to “Enjoy” Asylum' (2005) 17 IJRL $293,295$.

91 Goodwin-Gill and McAdam (n 2) 285, 310.

92 ibid 285-286.

93 Walter Suntinger, 'The Principle of Non-Refoulement: Looking Rather to Geneva than to Strasbourg?' (1995) 49 AJPIL 203, 224.

94 European Convention for the Protection of Human Rights and Fundamental Freedoms, as amended by Protocols Nos 11 and 14 (adopted 4 November 1950, entered into force 3 September 1953) 213 UNTS 222 (ECHR). 
Convention against Torture and Other Cruel, Inhuman or Degrading Treatment ${ }^{95}$ ), serving as supervisory mechanisms ${ }^{96}$ under international human rights instruments greatly supported the clarification of the complex legal nature of the non-refoulement rule. International human rights instruments introduced obligations towards states not to transfer a person to another country where he or she might face serious human rights violation such as, arbitrary deprivation of life, torture, or other cruel, inhumane or degrading treatment. ${ }^{97}$ For example, Articles 6 and 7 of the ICCPR prohibit arbitrary deprivation of life, torture, cruel, inhumane or degrading treatment or punishment. The UN Human Rights Committee in its General Comments No 20 and No 31 reiterated the non-derogable nature ${ }^{98}$ of Article 7, further establishing that the removal of a person to a place where he or she would face a real risk (a necessary and foreseeable consequence) would lead to a violation of obligations imposed upon the states under the ICCPR. ${ }^{99}$

Likewise, while the European Convention on Human Rights (ECHR) does not expressly enshrine the principle of non-refoulement, its competent organs, through their jurisprudence, have consistently affirmed the absolute and non-negotiable nature ${ }^{100}$ of its Article 3, which provides that "no one shall be subjected to torture or to inhuman or degrading treatment or punishment". ${ }^{101}$ Prohibition of torture as a jus cogens norm, alongside its legal significance, represents the fundamental moral principle for maintaining a human society. ${ }^{102}$

Furthermore, the extensive case law of the Court, including its seminal cases of Soering, ${ }^{103}$ Chahal, ${ }^{104}$ and Ahmed, ${ }^{105}$ illustrates the broader ratione personae scope ${ }^{106}$ of Article 3 of ECHR compared to Article 33 of the Refugee Convention. Article 3 of ECHR applies to any individual falling within its protection due to fearing ill-treatment, irrespective of the character ${ }^{107}$ and conduct ${ }^{108}$ of the individual or a danger that derives from him/her. ${ }^{109}$ Still, the Court has restricted ${ }^{110}$ the extensive scope of the nonrefoulement under Article 3 by establishing a high threshold of evidentiary requirements for its application. ${ }^{11}$ According to the Court's jurisprudence, ${ }^{112}$ establishing a minimum

95 International Covenant on Civil and Political Rights (adopted 16 December 1966, entered into force 23 March 1976) 999 UNTS 171 (ICCPR); Convention against Torture and other Cruel, Inhuman or Degrading Treatment or Punishment (adopted 10 December 1984, entered into force 26 June 1987) 1465 UNTS 85 (UNCAT).

96 Hurwitz, The Collective Responsibility of States to Protect Refugees (n 21) 187-189.

97 Goodwin-Gill and McAdam (n 2) 302, 308, 310-11, 316.

98 ICCPR art 4(2); UNHRC, 'CCPR General Comment No 20: Article 7 (Prohibition of Torture, or Other Cruel, Inhuman or Degrading Treatment or Punishment)' $(10$ March 1992) 3 available at: < https://www.refworld.org/docid/453883fb0.html> accessed on: 12.09.2021.

99 UNHRC, 'GT v Australia' (4 November 1997) UN Doc CCPR/C/61/0/706/1996 8.1.

100 See ECHR art 3; Council Directive 2011/95/EU art 15(b).

101 Soering v United Kingdom (1989) Series A no 161 [87]-[88], [90]-[91]; Cruz Varas v Sweden (1991) Series A no 201 [70]; Chahal v United Kingdom ECHR 1996-V 97 [74]; Saadi v Italy App no 37201/06 (ECHR, 28 February 2008) 125, 134-136.

102 Levan Alexidze, 'Legal Nature of Jus Cogens in Contemporary International Law' (1981) 172 Recueil des Cours 219, 260.

103 Soering $v$ United Kingdom (n 101).

104 Chahal v United Kingdom (n 101).

105 Ahmed v Austria ECHR 1996-VI 26.

106 ibid 41, Chahal v United Kingdom (n 101) [80].

107 Soering v United Kingdom (n 101); Chahal v United Kingdom (n 101).

108 Soering $v$ United Kingdom (n 101).

109 Chahal v United Kingdom (n 101) [80]; Ahmed v Austria (n 105) (criminal posing threat to national security).

110 Terje Einarsen, 'The European Convention on Human Rights and the Notion of an Implied Right to De Facto Asylum' (1990) 2 IJRL 361, 373, 384; Hélène Lambert, 'Protection against Refoulement from Europe: Human Rights Law Comes to the Rescue' (1999) 48(3) ICLQ 515, 517.

111 Hurwitz, The Collective Responsibility of States to Protect Refugees (n 21) 200. 
level of severity for the treatment is an essential prerequisite, while less favourable treatment towards individuals does not give rise to a breach of Article $3 .{ }^{113}$ As established in Vilvarajah, a mere possibility of ill-treatment does not suffice breach of Article $3,{ }^{114}$ since there should be substantial grounds for believing that upon removal, the person concerned would face a real ("foreseeable"115) risk of being subjected to torture or inhuman or degrading treatment or punishment. ${ }^{116}$ Apart from the apparent duty of nonreturn under Article 3, the state parties to the Convention might not be allowed to remove persons due to the real risk of ill-treatment giving rise to a breach of other provisions of the Convention as well. ${ }^{117}$ Thus, Article 3 may be considered as a protective shield suggesting "a right to de facto asylum" ${ }^{118}$ while precluding ${ }^{119}$ any exception or qualification even in time of war or public emergency. ${ }^{120}$

Notably, Article 3 of the UN Convention against Torture enshrines the explicit prohibition of the removal of a person when there are substantial grounds to believe that it will create a risk of being subjected to torture. Unlike the 1951 Refugee Convention, and in resemblance of the ICCPR, ECHR, American Convention on Human Rights and OAS Convention, ${ }^{121}$ this provision permits no derogation irrespective of the character or behaviour of the person concerned, as well as, regardless of whether he/she poses a danger to the state. ${ }^{122}$ The Committee against Torture has consistently affirmed that the standard of proof for Article 3 goes "beyond mere theory or suspicion" or "a mere possibility of torture"; ${ }^{123}$ rather, in order to qualify for protection, there should be substantial grounds for believing that the risk of torture is real, foreseeable and personal. ${ }^{124}$ However, the scope of the protection is different from the ICCPR, ECHR and 1951 Refugee Convention: Article 3 of the Convention against Torture provides protection from torture, which encompasses acts, carried out or acquiesced solely by the

112 Soering v United Kingdom (n 101) 100; Cruz Varas v Sweden (n 101) [83]; Vilvarajah and ors $v$ United Kingdom (1991) Series A no 215 107; Ahmet Özkan and ors $v$ Turkey App no 21689/93 (ECHR, 6 April 2004) [334]; Saadi v Italy (n 101) 134.

113 Katharina Röhl, 'Fleeing violence and poverty: non-refoulement obligations under the European Convention of Human Rights' (2005) UNHCR Working Paper no 111, 18 <https://www.unhcr.org/research/working/41f8ef4f2/fleeing-violence-poverty-non-refoulement-obligationsunder-european-convention.html> accessed 22 October 2020.

114 Vilvarajah and ors $v$ United Kingdom (n 112) 97.

115 Soering $v$ United Kingdom (n 101) 100.

116 ibid [91]; Cruz Varas v Sweden (n 101) 69, 82; Vilvarajah and ors v United Kingdom (n 112) 107, 115; Chahal v United Kingdom (n 101) 74; Ahmed v Austria (n 105) 39; H.L.R v France ECHR 1997-III 34; Abdurrahim Incedursun $v$ the Netherlands ECHR App no 33124/96 27; Jabari v Turkey ECHR 2000-VIII 38; Salah Sheekh v the Netherlands App no 1948/04 (ECHR, 11 January 2007) [135]; Saadi v Italy (n 101) 125 .

117 See $R$ v Special Adjudicator ex parte Ullah [2004] UKHL 26 [21], [24-5], [35], [39-50], [52-53], [62], [67].

118 Terje Einarsen (n 110) 382-5.

119 ECHR art 15(2); Soering v United Kingdom (n 101) 88; Vilvarajah and ors v United Kingdom (n 112) 108; Chahal v United Kingdom (n 101) 79-80; Ahmed v Austria (n 105) 40; Saadi v Italy (n 101) 127, 137-138.

${ }^{120}$ Hurwitz, The Collective Responsibility of States to Protect Refugees (n 21) 189-190.

121 Gorki Ernesto Tapia Paez v Sweden CAT/C/18/D/39/1996 (CAT, 28 April 1997) 14.5; Seid Mortesa Aemei v Switzerland CAT/C/18/D/34/1995 (CAT, 29 May 1997) [9.8]; Goodwin-Gill and McAdam (n 2) 302-303.

122 OAU Convention art II(3); American Convention on Human Rights (adopted 22 November 1969, entered into force 18 July 1978) (Pact of San Jose) art 22(8).

123 EA v Switzerland CAT/C/19/D/028/1995 (CAT, 10 November 1997) 11.3.

${ }^{124}$ See, for example, ibid 11.5; X, Y, and Z v Sweden CAT/C/20/D/61/1996 (CAT, 6 May 1998) 11.5; NMv Switzerland CAT/C/24/D/116/1998 (CAT, 9 May 2000) 6.7; SC v Denmark CAT/C/24/D/143/1999 (CAT, 10 May 2000) 6.6. 
state. ${ }^{125}$ It is further circumscribed to provide protection from pain or suffering arising out of "lawful sanctions". ${ }^{126}$ Likewise, the Inter-American Court of Human Rights has explicitly declared in its judgment on the Pacheco Tineo case, that the obligation to grant asylum exists if doing otherwise would violate the non-refoulement rule. ${ }^{127}$

All things considered, it can be claimed that the human rights protection regimes have established "the basic standards on which principled action can be based". ${ }^{128}$ However, these standards encompass multiple, yet diverse legal conditions regarding the scope of the non-refoulement rule and while doing so, guaranteeing the de facto right to asylum.

\section{Securing the right to asylum through the customary rule of non- refoulement, if any}

The determination of non-refoulement as a customary obligation has undoubted significance for its unlimited application to all states, including those who are not bound by treaty law. The rules of customary international law have particular importance for the human rights protection regime where treaty provisions might not bind numerous states, or when there is an urgent need for interpreting, applying or modifying relevant treaty provisions. ${ }^{129}$

The behavioural regularity and acknowledgement of legality ${ }^{130}$ represent the foundation of customary rule. ${ }^{131}$ Kelsen explained custom as "unconscious and unintentional law-making". ${ }^{132}$ Visscher described the customary rule as the expression of the 'deeply felt community of law' ${ }^{133}$ Likewise, Judge Read envisaged customary international law as "the generalisation of the practice of states" 134 which, according to Anzilotti, should be observed with the conviction of complying with certain obligation. ${ }^{135}$

Indeed, to be regarded as international customary rule, a consistent state practice should be accompanied by the belief that adherence to the rule reflects and is required by law. ${ }^{136}$ While according to Ulpian, such "two-element theory" can be traced back to the $1^{\text {st }}$ century A.D. in Roman Law, ${ }^{137}$ the modern, ${ }^{138}$ close-to-universal definition of

125 J Herman Burgers and Hans Danelius, The United Nations Convention against Torture: A Handbook on the Convention against Torture and Other Cruel, Inhuman or Degrading Treatment or Punishment (Brill 1988) 119-20; H.L.R v France (n 116) 40; Goodwin-Gill and McAdam (n 2) 301.

126 Goodwin-Gill and McAdam (n 2) 301.

127 Familia Pacheco Tineo v Estado Plurinacional de Bolivia, Inter-American Court of Human Rights, Serie C No. 272, 25 November 2013, 2; see also, Gil-Bazo (n 3) 10.

128 Erika Feller, 'International Refugee Protection 50 years on: The Protection Challenges of the past, present and future' (2001) 83 IRRC 582.

129 See, Michael Byers, Custom, Power and the Power of Rules, International Relations and Customary International Law (CUP 2004) 4, 166-80.

130 ibid 3.

131 Malcolm N Shaw, International Law (8th edn, CUP 2017) 54.

132 Antonio Cassese, International Law (2 ${ }^{\text {nd }}$ edn, OUP 2005) 156; see also, International Law Commission (André da R Ferreira, Cristieli Carvalho, Fernanda G Machry, Pedro B V Rigon), 'Formation and Evidence of Customary International Law' (2003) 1 UFRGSMUN 186.

133 Charles De Visscher, Theory and Reality in Public International Law (Percy Ellwood Corbett edn, PUP 2016) 155; see also, Alexander Orakhelashvili, 'Natural Law and Customary Law' (2008) MPICPLIL 81.

${ }^{134}$ Fisheries (United Kingdom v Norway) (Dissenting Opinion of Judge Read) [1951] ICJ Rep 186 (Fisheries); see also, James R Crawford, Brownlie's Principles of Public International Law (8th edn, OUP 2015) 23.

135 D Anzilotti, Cours de droit international (Gilbert Gidel tr, Recueil Sirey 1929) 73-74.

136 ILC, 'Formation and Evidence of Customary International Law' (n 132) 182, 187.

137 Ulpian, 'Tituli ex corpore Ulpiani' in Paul F Girard and Félix Senn (eds), Textes de droit romain, (vol 1, 7th edn, Dalloz 1967).

138 Statute of the International Court of Justice (adopted 26 June 1945, entered into force 24 October 1945) 33 UNTS 993 (ICJ Statute) art 38(1)(b). 
customary rule is provided by Article 38 of the Statute of the ICJ, which refers "international custom, as evidence of a general practice accepted as law". ${ }^{139}$ The jurisprudence of the ICJ ${ }^{140}$, and its predecessor PCIJ ${ }^{141}$ has established the need of the cumulative presence of both constituent elements of international customary rule: state practice and opinio juris.

At the UN Conference on the Status of Stateless Persons, ${ }^{142}$ the non-refoulement rule was proclaimed as a general principle of international law, approximately three years after one of its first conventional stipulations in the 1951 Refugee Convention. ${ }^{143}$ Even though scholars have further assessed this statement as premature, ${ }^{144}$ the principle of nonrefoulement has greatly evolved during these 60 years in international practice ${ }^{145}$ and treaty law ${ }^{146}$ alongside the realisation of the right to asylum. Having 147 states to be now bound by the conventional obligation of non-refoulement, the norm-creating character of this principle has been well established ${ }^{147}$ by international conventions, ${ }^{148}$ UNHCR Executive Committee Conclusions, ${ }^{149}$ UN General Assembly Resolutions, ${ }^{150}$ etc. The customary nature of the principle of non-refoulement is highly asserted by majority of prominent scholars, ${ }^{151}$ while some of distinguished scholars, such as Hathaway and Hailbronner, dispute that the standard for establishing the customary rule has not been yet attained as interstate practice illustrates noncompliance. ${ }^{152}$

139 ibid art 38(1)(b).

140 Asylum case (Colombia v. Peru) (Haya de la Torre case) (Merits) [1950] ICJ Rep 395 (Asylum case); see also, North Sea Continental Shelf cases (Federal Republic of Germany/Denmark, Federal Republic of Germany/The Netherlands) (Merits) [1969] ICJ Rep 3 (North Sea Continental Shelf cases) [37]; Military and Paramilitary Activities in and against Nicaragua (Nicaragua $v$ United States) (Judgment) [1986] ICJ Rep 14 (Nicaragua) 98.

141 SS 'Lotus' (France v Turkey) (Merits) [1927] PCIJ Series A no 10 (Lotus).

142 Convention relating to the Status of Stateless Persons (adopted 28 September 1954, entered into force 6 June 1960) 360 UNTS 117.

143 See also, Convention Relating to the International Status of Refugees (adopted 28 October 1933, entered into force 13 June 1935) 159 LNTS 3663, art 3.

144 Hurwitz, The Collective Responsibility of States to Protect Refugees (n 21) 204; Goodwin-Gill and McAdam (n 2) 345 .

145 see e.g. UNHCR Advisory Opinion (n 42) [15]; Hurwitz, The Collective Responsibility of States to Protect Refugees (n 21) 204; Goodwin-Gill and McAdam (n 2) 345; Zimmermann, Machts, Dörschner (n 17$) 1411$.

146 See ECHR; ICCPR; UNCAT.

147 Hurwitz, The Collective Responsibility of States to Protect Refugees (n 21) 204-205.

148 OAU Convention art II(3); Declaration on Territorial Asylum, art 3(1); CoE Committee of Ministers Resolution (67) 14 (n 27); Cartagena Declaration on Refugees; AALCO, Bangkok Principles (n 65) arts III.3, III.5; Geneva Convention Relative to the Protection of Civilian Persons in Time of War (Fourth Geneva Convention) (adopted 12 August 1949, entered into force 21 October 1950) 75 UNTS 287 art 45.

149 UNHCR ExCom Conclusion 6 (1977) [a]; UNHCR ExCom Conclusion 17 (1980) [d]; UNHCR ExCom Conclusion 68 (1992) [f]; UNHCR ExCom Conclusion 71 (1993) [g]; UNHCR ExCom Conclusion 74 (1994) [g]; UNHCR ExCom Conclusion 79 (1996) [j]; UNHCR ExCom Conclusion 81 (1997) [i]; UNHCR ExCom Conclusion 99 (2004) [1]; UNHCR ExCom Conclusion 103 (2005) [m].

${ }^{150}$ Including: UNGA res 32/67 (8 December 1977) A/RES/32/67 [5(c)]; UNGA res 33/26 (29 November 1978) A/RES/33/26 [6]; UNGA res 60/120 (16 December 2005) A/RES/60/120 [3]; UNGA res 60/129 (24 January 2006) A/RES/60/129 [3]; UNGA res 61/137 (25 January 2007) A/RES/61/137 [3]; UNGA res 62/124 (24 January 2008) A/RES/62/124 [4].

151 Weis, 'Legal Aspects of the Convention of 28 July 1951 relating to the Status of Refugees' (n 62) 482; David Martin, 'The New Asylum Seekers' in David Martin (ed), The New Asylum Seekers: Refugee Law in the 1980s: The Ninth Sokol Colloquium on International Law (Nijhoff 1988); Goodwin-Gill and McAdam (n 2) 346.

152 James C Hathaway, The Rights of Refugees under International Law (CUP 2005) 363. 


\section{i. States' compliance with the principle of non-refoulement: rules against practice}

States are entities that enjoy international legal personality and their conduct, actions as well as omissions, ${ }^{153}$ can widely evidence the customary nature of the non-refoulement rule. ${ }^{154}$ It involves the practice of their executive, legislative and judicial organs, as well as those private persons and entities that act on their behalf. ${ }^{155}$ The formation and expression of the customary rule of non-refoulement can also be affected by the practice of international organisations, ${ }^{156}$ non-governmental organisations, multinational corporations and even individuals. ${ }^{157}$ As ILC observed, the customary rule can by evidenced by taking due regard to subjects, forms, the general nature and duration of such practice. ${ }^{158}$

Practice regarding the non-refoulement rule can be evidenced by physical and verbal acts, ${ }^{159}$ such as, but not limited to: diplomatic acts and correspondence, acts of the judiciary, legislature, or executive branch of government, conduct in connection with treaties and resolutions of the UN General Assembly, etc. ${ }^{160}$ The particular duration of time is not essential for the determination of the existence of customary rule of nonrefoulement if the practice is maintained or repeated. ${ }^{161}$ The ICJ affirmed in the North Sea Continental Shelf cases that the passage of only a short period of time was not an impediment for the formation of a new international customary rule if there was fulfilled one "indispensable requirement" that state practice should be extensive and virtually uniform, as well as it "should moreover have occurred in such a way as to show a general recognition that a rule of law or legal obligation is involved". ${ }^{62}$

Generality of state practice is an essential precondition for establishing the customary nature of the non-refoulement rule. The ILC has defined the generality of practice as "the aggregate of the instances in which the alleged rule of customary international law has been followed". ${ }^{163}$ The states' observance of the non-refoulement rule can be considered as general or a "settled practice" 164 if it fulfils two requirements: firstly, if the adherence of the non-refoulement rule is sufficiently widespread and representative; and secondly, if such adherence is consistent. ${ }^{165}$ For the non-refoulement rule to be widespread, universal participation by all states is not required; rather a

153 ILC, 'Formation and Evidence of Customary International Law' (n 132) 187.

154 International Law Commission, 'Draft Conclusions on Identification of Customary International Law, with commentaries' (2018) vol 2(2) ILCYB 130.

155 Maurice H Mendelson, The Formation of Customary International Law (Nijhoff 1999) 198.

156 Shaw (n 131) 241; ILC, 'Formation and Evidence of Customary International Law' (n 132) 188; ILC, 'Draft Conclusions on Identification of Customary International Law' (n 154) 130.

157 Mendelson, The Formation of Customary International Law (n 155) 203; ILC, 'Formation and Evidence of Customary International Law' (n 132) 188.

158 ILC, 'Formation and Evidence of Customary International Law' (n 132) 187.

159 ibid 189; ILC, 'Draft Conclusions on Identification of Customary International Law' (n 154) 133; Mendelson, The Formation of Customary International Law (n 155).

${ }^{160}$ ILC, 'Formation and Evidence of Customary International Law' (n 132) 188; ILC, 'Draft Conclusions on Identification of Customary International Law' (n 154) 133; see also, Crawford (n 134) 24.

161 ILC, 'Draft Conclusions on Identification of Customary International Law' (n 154) 136; Crawford (n 134) 24.

162 North Sea Continental Shelf cases [74]; ILC, 'Draft Conclusions on Identification of Customary International Law' (n 154) 138; ILC, 'Formation and Evidence of Customary International Law' (n 132) 189; Crawford (n 134) 24.

163 ILC, 'Draft Conclusions on Identification of Customary International Law' (n 154) 136.

164 North Sea Continental Shelf (n 77).

165 ILC, 'Draft Conclusions on Identification of Customary International Law' (n 154) 135-136. 
sufficient number of states, including those who had an opportunity or possibility to adhere it should implement the prohibition from refoulement. ${ }^{166}$ Likewise, according to the findings of ICJ in the Fisheries case and the ILC draft Conclusions, the consistency, or discernible pattern of behaviour of the states, ${ }^{167}$ requires substantial not complete uniformity. ${ }^{168}$

Having no single case when the state has ever expelled refugees by calling it a refoulement, ${ }^{169}$ seems like a promising foundation to evidence the generality of nonrefoulement rule. However, Hathaway's conclusion represents the irrefutable truth that, "as the recounting of state practice [...] makes depressingly clear, refoulement still remains part of the reality for significant numbers of refugees, in most parts of the world". ${ }^{170}$ Close observance of state reports to the Human Rights Committee and the Committee against Torture evidences that states do not usually refer their expulsions, deportations, refusals to admit or removals as instances of refoulement. ${ }^{171}$

Having due regard to the violations of the non-refoulement rule, there arises the key question of whether such occurrences diminish the consistency of the customary rule. In the Asylum case, the ICJ defined that for the means of establishing international customary rule, the complete uniformity of the practise is not required, rather a customary rule must be "in accordance with a constant and uniform usage practised by the states in question". ${ }^{172}$ This approach was reiterated in the North Sea Continental Shelf cases $^{173}$ and further elaborated in the Nicaragua case, where ICJ held that for the establishment of customary rule, it is not necessary that the corresponding practice to be "in absolutely rigorous conformity with the rule"; instead, "the conduct of states should, in general, be consistent with such rules". ${ }^{174}$ The Court furthermore noted that the inconsistencies in the state conduct could not be used as a proof of the emergence of a new rule. Rather, they point to the breach of the customary rule, given that the state breaching the rule defends its conduct by referring to exceptions or justifications enshrined within the rule itself. ${ }^{175}$ As Goodwin-Gill and McAdam note, ${ }^{176}$ a number of states describe their conduct as "something other" than refoulement while closing their borders to the refugees, ${ }^{177}$ avoiding calling accepted migrants as refugees by insisting that they were receiving them due to humanitarian concern, ${ }^{178}$ or justifying deportations as expelling illegal migrants. ${ }^{179}$ It is undoubtedly clear that irrespective of being bound by

\footnotetext{
166 ibid 136.

167 Fisheries [131]; Delimitation of the Maritime Boundary in the Gulf of Maine Area (Canada v United States) (Merits) [1984] ICJ Rep 165 (Gulf of Maine Area) [81].

168 ibid 116, 131, 138; see also, Crawford (n 134) 24; Shaw (n 131) 57.

169 Goodwin-Gill and McAdam (n 2) 351.

170 Hathaway (n 152) 364; see also, UNHRC res 1997/75 (18 April 1997) E/CN.4/RES/1997/75; UNHCR, 'Note on International Protection', UN Doc A/AC.96/898 (3 July 1998) [10-14]; Hathaway and Dent (n 79) 5.

171 Goodwin-Gill and McAdam (n 2) 352.

172 Asylum case (n 140) 276-7; ILC, 'Formation and Evidence of Customary International Law' (n 132) 189; Shaw (n 131) 56.

173 North Sea Continental Shelf (n 77) 43.

174 Nicaragua (n 140) 186.

175 ibid.

176 Goodwin-Gill and McAdam (n 2) 352.

177 ibid 219, 227, 229-32, 347.

178 Donald W Greig, 'The Protection of Refugees and Customary International Law' (1983) 8 AYIL 108, 125-7; Patricia Hyndman, 'Asylum and Non-Refoulement - Are these Obligations Owed to Refugees under International Law?' (1982) 57 PLJ 43, 70-1.

179 Goodwin-Gill and McAdam (n 2) ch 5(2.5.1).
} 
conventional obligations of non-refoulement, states have asserted to great lengths their conduct to be in compliance with the principle of non-refoulement, even when the contrary was obvious. ${ }^{180}$ Thus, the balancing relationship between opinio juris and state practice should be given due regard, ${ }^{181}$ since even inconsistencies do not always avert the establishment of a customary rule. ${ }^{182}$

\section{ii. Evidencing opinio juris on non-refoulement rule}

Prohibition of refoulement with the sense of a legal right or obligation is a constituent element in establishing the existence of legal custom of non-refoulement rule. ${ }^{183}$ While everything that is mandated by morality, comity, courtesy or social needs does not evidence the legal rule, the rationale behind the psychological, subjective facet and opinio juris ${ }^{184}$ lies in distinguishing the practice that is established on legal conviction from those practices that are not. ${ }^{185}$

The absence of legal conviction has been a decisive factor in denying the existence of customary rule in Lotus. ${ }^{186}$ Similarly, in the Asylum case ${ }^{187}$ it was maintained that the presence of political expediency while lacking the sense of legal obligation refuted to evidence customary rule. ${ }^{188}$ As ILC explained, "a general practice that is accepted as law (opinio juris) is to be distinguished from mere usage or habit" 189 and be undertaken with the belief that such conduct is permitted, required or prohibited by customary rules. ${ }^{190} \mathrm{In}$ 1969 the ICJ established in the North Sea Continental Shelf judgement, the judicial locus classicus on the matter, ${ }^{191}$ that the state conduct should be the evidence of a belief that by acting so 'they are conforming to what amounts to a legal obligation'. ${ }^{192}$ The Court in the Nicaragua case corroborated the same approach. ${ }^{193}$

The coexistence of opinio juris alongside with state practice should be properly evidenced in order to assert the existence of customary rule of non-refoulement. ${ }^{194}$ While there exists no formal judicial declaration, the principle of non-refoulement has been consistently endorsed by UN member states as part of customary international law, ${ }^{195}$ most prominently by the Global Consultations on International Protection, ${ }^{196}$ the 2016

${ }^{180}$ Hathaway (n 152) 364; See also, Oscar Schachter, International Law in Theory and Practice (Nijhoff 1991) 337-40; cf Bruno Simma and Philip Alston, 'The Sources of Human Rights Law: Custom, Jus Cogens, and General Principles' (1988-89) 12 AYIL 82; Goodwin-Gill and McAdam (n 2) 352.

181 Schachter (n 180) 716, 735.

182 ILC, 'Draft Conclusions on Identification of Customary International Law' (n 154) 137.

183 ibid 138.

184 François Gény, Méthode D'interprétation et Sources en Droit Privé Positif: Essai Critique (2nd edn, LGDJ 1919).

185 Committee on Formation of Customary (General) International Law, 'Statement of Principles Applicable to the Formation of General Customary International Law' in International Law Association Report of the Sixty-Ninth Conference (London 2000) (International Law Association, London 2000) 10.

186 Lotus (n 141) 28.

187 Asylum case (n 140).

188 See also Orakhelashvili (n 133) 85.

189 ILC, 'Draft Conclusions on Identification of Customary International Law' (n 154) 138.

190 ibid.

191 Hugh Thirlway, The Sources of International Law (OUP 2014) 102.

192 North Sea Continental Shelf cases (n 77) 44, 77.

193 Nicaragua (n 140) 108-109.

194 North Sea Continental Shelf cases (n 77).

195 United States Diplomatic and Consular Staff in Tehran (United States of America v Iran) (Merits) [1980] ICJ Rep 3 [88]; See also Goodwin-Gill and McAdam (n 2) 346.

196 UNHCR, Declaration of States Parties to the 1951 Convention and/or Its 1967 Protocol relating to the Status of Refugees, HCR/MMSP/2001/09 (16 January 2002) [4], incorporated in ExCom of the High Commissioner's Program, Agenda for Protection (26 June 2002) UN Doc EC/52/SC/CRP9/Rev.1. 
New York Declaration for Refugees and Migrants, ${ }^{197}$ and the 2018 Global Compact on Refugees. ${ }^{198}$

As it has been rightly asserted by the ILC, opinio juris might be manifested by the same conduct used to confirm state practice, ${ }^{199}$ such as: public statements made on behalf of states, positions of states before international organisations or international conferences, state's actual conduct, state's treaty practice, government legal opinions, diplomatic practice, pronouncements/decisions of national courts, etc. ${ }^{200}$ Accession to treaties by states can also be considered as an evidence to opinio juris, since states behave so due to their belief that this is the right thing to do. The norm creating character of the principle of non-refoulement has been also routinely pronounced by UN General Assembly resolutions and UNHCR. ${ }^{201}$ As an example, the ICJ has inferred the existence of opinio juris from the UN General Assembly resolutions, ${ }^{202}$ its own or other tribunals' practice, ${ }^{203}$ as well as major codification conventions ${ }^{204}$ and the work of the ILC. ${ }^{205}$ Likewise, states refrain from making formal or informal opposition to the principle, while invariably acknowledging its normative character irrespective of being a state party to the 1951 Refugee Convention or 1967 Protocol. ${ }^{206}$

As a general rule, the establishment of a customary rule of non-refoulement guarantees its unequivocal application and uniform interpretation among all states irrespective of their assignment to conventional obligations. ${ }^{207}$ Therefore, the unhindered application of the non-refoulement rule itself should represent as a major assurance for respecting and enforcing the right to asylum. However, as illustrated above, the scope and composition of the non-refoulement rule is not identical in customary and treaty law, causing its multi-layered interpretation and application, including regarding refugee matters.

197 New York Declaration 24, 58, 67.

198 Global Compact on Refugees 5, 87.

199 ILC, 'Formation and Evidence of Customary International Law' (n 132) 191; International Law Association, Report of the Sixty-Ninth Conference (n 185) 7.

200 ILC, 'Draft Conclusions on Identification of Customary International Law' (n 154) 140; ILC, 'Formation and Evidence of Customary International Law' (n 132) 21.

201 UNHCR ExCom Conclusion 6 (1977) [a]; UNHCR ExCom Conclusion 17 (1980) [d]; UNHCR ExCom Conclusion 68 (1992) [f]; UNHCR ExCom Conclusion 71 (1993) [g]; UNHCR ExCom Conclusion 74 (1994) [g]; UNHCR ExCom Conclusion 79 (1996) [j]; UNHCR ExCom Conclusion 81 (1997) [i]; UNHCR ExCom Conclusion 99 (2004) [1]; UNHCR ExCom Conclusion 103 (2005) [m]; see ftn 140.

202 See e.g. Legality of the Threat or Use of Nuclear Weapons (Advisory Opinion, 8 July 1996) [Nuclear Weapons] 226, 254-255.

203 North Sea Continental Shelf cases (n 77) 3, 44; Gulf of Maine Area [246], [293]-[294]; Nicaragua (n 140) 14, 108-109; Nuclear Weapons (n 202) 226, 254-255; Pulp Mills on the River Uruguay (Argentina v Uruguay) (Merits) [2010] ICJ Rep 14 203-206.

204 See e.g. North Sea Continental Shelf cases (n 77) 3, 28-32; The Land and Maritime Boundary between Cameroon and Nigeria (Cameroon v Nigeria: Equatorial Guinea Intervening) (Merits) [2002] ICJ Rep 303, 429-30.

205 See e.g. Gabcíkovo-Nagymaros case (Hungary v Slovakia) (Merits) [1997] ICJ Rep 7, 38-42, 46.

206 UNHCR, 'The Principle of Non-Refoulement as a Norm of Customary International Law. Response to the Questions Posed to UNHCR by the Federal Constitutional Court of the Federal Republic of Germany in Cases 2 BvR 1938/93, 2 BvR 1953/93, 2 BvR 1954/93' (31 January 1994) [5] available at:<https://www.refworld.org/docid/437b6db64.html> accessed on 11.09.2021; see also, Goodwin-Gill and McAdam (n 2) ch 5(2.5) 347.

207 Hurwitz, The Collective Responsibility of States to Protect Refugees (n 21) 207. 


\section{Common Understanding of the Foundational Principles of Right to Asylum and Non-Refoulement Rule as Conditio Sine Qua Non for Functioning of Predictable and Equitable Burden- and Responsibility-Sharing Mechanism}

Refugee issues is a matter of transnational importance ${ }^{208}$ and consequently, states have a general obligation of international cooperation to provide protection to refugees, as it has been duly referred in 1951 Refugee Convention ${ }^{209}$ and the Global Compact on Refugees. ${ }^{210}$ As Volker Türk and Madeline Garlick point out:

[...] the legal obligation for States to cooperate with each other in regard to refugee matters, directly among themselves and via cooperation with UNHCR, [...] emerges from the UN Charter, UNHCR's Statute, and subsequent relevant UNGA resolutions in conjunction with the 1951 Convention, as well as other international refugee instruments and corresponding State practice. ${ }^{211}$

While this proclamation provides veracity, the diversified understanding of the foundational principles of refugee protection regime, the right to asylum and the nonrefoulement rule, makes it difficult to identify common protection needs and therefore, the respective responsibilities of states regarding international cooperation and burdenand responsibility-sharing on refugee matters. This section examines whether these deficiencies in the global refugee regime consequently affect the predictable and equitable allocation of responsibilities among states, particularly, while guaranteeing the right to asylum. ${ }^{212}$

Diversified approaches to the application of the right to asylum alongside with manifold interpretations of the non-refoulement rule can be considered as the reason behind failing refugee protection regimes. Recent experience illustrates that while concern regarding refugees has drastically increased due to previous and existing conflicts, massive violations of human rights and environmental degradation, this has imposed intolerable responsibilities and costs to low or middle-income developing countries. ${ }^{213}$ Consequently, there is a pattern of defensive strategies by states to avoid receiving those who had to leave their homes forcibly. ${ }^{214}$

While the right to seek asylum is not accompanied with the corresponding state's duty to grant asylum, states enjoy full discretion of interpreting their obligations under the existing refugee protection regime and to design their individual approaches and asylum policies. ${ }^{215}$ Consequently, the lack of common understanding of the right to asylum and non-refoulement rule causes vivid confusion regarding the corresponding

\footnotetext{
208 James C Hathaway, R Alexander Neve, 'Making International Refugee Law Relevant Again: A Proposal for Collectivised and Solution-Oriented Protection' (1997) 10 HHRJ 115, 170.

209 Refugee Convention, Preamble, Recital 4.

${ }^{210}$ Global Compact on Refugees, paras 2, 48, Annex I paras 1, 9.

211 Volker Türk and Madeline Garlick, 'From Burdens and Responsibilities to Opportunities: The Comprehensive Refugee Response Framework and a Global Compact on Refugees’ (2016) 28 IJRL 660.

212 Catherine Phuong, 'Identifying States' Responsibilities towards Refugees and Asylum Seekers' (2005) ESIL Research Forum <http://www.esilsedi.eu/sites/default/files/Phuong.PDF> accessed 20 September 2020, 11.

${ }^{213}$ Hathaway and Neve (n 208) 116.

214 ibid.

215 Yvonne S Brakel, Rachel E Kester, Samantha L Potter, '50 Years Was Too Long to Wait: The Syrian Refugee Crisis Has Highlighted the Need for a Second Optional Protocol to the 1951 Convention Relating to the Status of Refugees' (2017) 40 UALRLR 51, 55, 59; Phuong (n 212) 1.
} 
international obligations of states towards asylum seekers and refugees. ${ }^{216}$ As a result, the manipulability ${ }^{217}$ of the definition of these legal guarantees considerably weakens the functioning of the global refugee regime.

As Goodwin-Gill has pointed out, "the peremptory norm of non-refoulement secures admission". ${ }^{218}$ However, given the "longstanding unwillingness by states to codify a global obligation to share responsibility for refugees", ${ }^{219}$ admission of asylum seekers and refugees is one of such dimensions where fragmentation in the right to asylum and non-refoulement rule results in diverse practices between states. ${ }^{220}$ In theory, admission of asylum seekers is a precondition for states to perform their conventional obligation of non-refoulement in good faith ${ }^{221}$ However, states can equally deny admission due to the existence of "safe third country" option that, in practice, might lead to having "orbit refugees" - who want to seek asylum but are rejected by each country as they have had the possibility to seek asylum earlier in another safe country and can return there.

In the absence of a common understanding, the "safe third country" practices, on the one hand, equip states with the discretion to reject such refugees at the border, and by doing so, provides them ample opportunity to interpret the right to asylum and the nonrefoulement rule on a case-by-case basis. ${ }^{222}$ On the other hand, states usually claim the expulsion of non-citizens as something different from refoulement. While the international community should respect the discretionary acts of the states as sovereigns, protection of those in need is a fundamental precondition for the functioning of the global refugee regime. Functionality of the regime now depends on whether states and the international community as a whole can agree on the substance of the value from which the global refugee regime was brought into being.

Another substantive lacunae ${ }^{223}$ in the understanding of the right to asylum and non-refoulement rule is the vagueness of state responsibility for processing asylum claims in or outside the state where the application is lodged. ${ }^{224}$ As early as the 1990s, states have been reluctant to examine asylum cases lodged on their territories. ${ }^{225}$ While there is no explicit legal provisions that refers to the location of the examination, it is hardly imaginable to set up equitable and predictable burden- and responsibility-sharing mechanism without shedding light to this issue. ${ }^{226}$

While governments have regularly endorsed the importance of international solidarity and burden sharing, collectivised efforts have been ad hoc and usually insufficient, ${ }^{227}$ which has ultimately caused "asylum fatigue" to traditional receiving

\footnotetext{
216 Phuong (n 212) 1.

217 Edwards, 'Human Security and the Rights of Refugees: Transcending Territorial and Disciplinary Borders' (n 89) 796.

218 Goodwin-Gill and McAdam (n 2) 202.

219 David J Cantor, 'Fairness, Failure, and Future in the Refugee Regime' (2018) 30(4) IJRL 627, 628.

220 Brakel, Kester, Potter (n 215) 59.

221 VCLT art 26.

222 Phuong (n 212) 3.

${ }^{223}$ Edwards, 'Human Security and the Rights of Refugees: Transcending Territorial and Disciplinary Borders' (n 89) 796.

${ }^{224}$ Rosemary Byrne and Andrew Shacknove, 'The Safe Country Notion in European Asylum Law' (1996) 9 HHRJ 185; Phuong (n 212) 4.

225 Joanne V Selm-Thorburn, Refugee Protection in Europe: Lessons from the Yugoslav Crisis (The Hague: Nijhoff 1998); Phuong (n 212) 4.

226 Phuong (n 212) 4-5.

227 Hathaway and Neve (n 208) 116.
} 
states. The global refugee regime suffers from the lack of apparent identification of the relevant responsibilities of states towards asylum seekers and refugees within the scope of the right to asylum and non-refoulement rule. Consequently, fragmentation in these concepts represents a hindering factor to well functioning burden and responsibilitysharing mechanism, and in the long term, to the functioning of the global refugee regime. The common approach on the right to asylum and non-refoulement rule will ultimately enhance the accountability of states and burden- and responsibility-sharing in refugee context.

\section{Conclusion}

Examining international jurisprudence on refugee matters and human rights has revealed the ambiguity in interpreting and applying core principles of refugee protection regime. In the absence of the universally accepted approach on the right to asylum, the rights to seek, be granted and enjoy asylum represent interconnected, but independent and partitioned concepts. Therefore, diversified, yet contrasting, approaches are still applied in interpreting the right to asylum and the non-refoulement rule. Such fragmentation represents a hindering factor to equitable and predictable burden- and responsibilitysharing mechanism, and in the long term, to the functioning of the global refugee regime as a whole.

After some 70 years following the establishment of the current refugee regime, the asylum dilemma progressively aggravates. The current refugee regime has moderately affixed precision to the legal protection towards those in need of asylum. However, application of the established standards illustrated invisible lacunas. This article suggested the analysis of the nature, composition and enforceability of the right to asylum and its protecting shield - the non-refoulement rule, by examining their sequel on the operation of equitable and predictable protection regime. Attaining a common understanding on the core values will serve as an ultimate precondition on the way to establishing and securing equitable and predictable burden- and responsibility-sharing mechanism in refugee context. Indeed, the major, yet incomplete, transformations in refugee matters over the decades evidences that the $21^{\text {st }}$ century is no less transitional than its preceding one. 